Article

\title{
Valuation of Ecosystem Services from Wetlands Mitigation in the United States
}

\section{Naveen Adusumilli}

Louisiana State University Agricultural Center (LSU AgCenter), Red River Research Station, Bossier City, LA 71112, USA; E-Mail: nadusumilli@agcenter.lsu.edu; Tel.: +1-318-741-7430

Academic Editor: Audrey L. Mayer

Received: 8 October 2014 / Accepted: 28 February 2015 / Published: 6 March 2015

\begin{abstract}
Section 404 of the U.S. Clean Water Act includes most wetlands in its jurisdiction and requires wetland mitigation to compensate for permitted wetland losses. These mitigation wetlands can provide ecosystem services similar to original wetlands if properly constructed. Improvement of wetland monitoring requirements coupled with economic assessment is critical for effective implementation of the mitigation policy. The economic assessment when left out of evaluation of mitigation policy could result in mitigation wetlands being given too little weight in policy decisions. Under the assumption that mitigation requirements reported in the Army Corps permit files represent actual wetland creation, ecosystem services value is estimated using a wetland benefit-function transfer approach. Wetland mitigation requirements during 2010-2012 recorded in the Army Corps permit files is used for the analysis. The results indicate that cumulative ecosystem services value per acre per year is in the range of $\$ 5000$ to $\$ 70,000$, which translates to a nationwide annual aggregate benefit of $\$ 2.7$ billion. Given the history of the ecosystem services not fully captured nor adequately quantified, the current analysis is an initial step in understanding the value of wetland mitigation.
\end{abstract}

Keywords: clean water act; wetland; ecosystem; mitigation; benefit function transfer

\section{Introduction}

Wetlands provide a host of ecosystem services [1], a term often used to indicate goods and services provided by ecosystems that benefit humankind [2]. These services include water filtration, flood protection, recreational opportunities, and wildlife habitat, among others. Various studies have addressed 
the valuation of these ecosystem services. Specific economic valuations include fishery production value of Florida coastal marshes [3]; recreational value of Michigan coastal wetlands [4]; and hurricane protection value of U.S. coastal wetlands [5]. In spite their potential to offer multiple ecosystem services that have positive economic benefits, a great deal of original wetland habitat in the continental U.S. has been lost, decreasing from 221 million acres in 1780 [6] to 110.1 million acres by 2009 [7]. Several causes for wetland losses have been investigated by Fish and Wildlife Service and Natural Resources Conservation Service. Agriculture, silviculture, rural and urban development were identified as the main drivers of wetland losses [7]. Although wetlands conversion to agriculture dominated in the early 1900's, wetland conversion to urban and rural development and silviculture dominated in the 2000's. Approximately, 268,000 acres and 325,000 acres of freshwater and saltwater wetlands losses were attributed to urban and rural development, and silviculture, respectively, during 1998-2009 [7]. Nevertheless, with society increasingly aware of the ecological and economic benefits of wetlands, a variety of policies has been adopted to protect the wetlands. Most notable among them is Section 404 of the Clean Water Act (hereafter "CWA" or "the Act").

Section 404 of the Act includes most wetlands in its jurisdiction and requires permits for the discharge of dredged or fill material into water bodies, including wetlands. The U.S. Army Corps of Engineers (USACOE), in conjunction with the U.S. Environmental Protection Agency (U.S. EPA), regulates the placement of dredged or fill material into these wetlands by determining whether to issue a permit, issue a permit with mitigation, or to deny a permit. The sequence of actions that must be followed to offset any impacts to aquatic resources, which the EPA and the USACOE together determined is a three-part process, known as the mitigation sequence. The objective of this process is to guide decisions and determine the type of mitigation required under the Act. The three-steps are avoid, minimize, and compensate. In avoid, any adverse impacts to the aquatic resources are to be avoided if a practicable alternative with les adverse impacts exists. In minimize, appropriate steps are to be taken to minimize the impacts in case the impacts cannot be avoided. In compensate, appropriate and practicable compensatory mitigation is required for unavoidable adverse impacts. Mitigation, which is a cornerstone of Section 404 of the Act, requires wetland establishment, preservation, and/or enhancement to compensate for permitted wetland losses [8]. Functional assessment models to determine mitigation ratios and mitigation requirements are determined using models that use location, hydrology, and hydrodynamics of wetlands [9]. Section 404 of the Act has undoubtedly helped maintaining and, in some cases, improving the status quo with respect to wetlands by avoiding losses of some of the ecosystem services that occur due to wetland destruction.

A number of previous studies have evaluated the effectiveness of Section 404 permits with respect to the mitigation program $[10,11]$. However, the monetized value of these restored wetlands based on ecosystem services was not assessed. Identification and valuation of the ecosystem services are two important steps that must be considered when protecting the wetland ecosystems [12]. Failure to quantify ecosystem values often results in an implicit value of zero being placed on the resources, but in most cases, ecosystems and the services have values larger than zero [13]. Moreover, lack of information about the value of wetlands mitigated often result in debates whether certain wetlands deserve protection at all. Hence, these policy discussions will be informed by efforts to quantify the ecosystem service value of wetlands and to use mitigation projects as a basis for evaluating the benefits that the Act provides. 
Economic valuation often depends on people's perception of the impact of an environmental resource on their well-being. It is measured in terms of willingness to pay for the resource and its services, wetlands in this case. Often values are also determined by the resource rarity. Benefit value accounts for all components of utility (disutility) derived from ecosystems using a common unit-money, which allows comparison of the tradeoffs of the need for economic development with environmental protection [14].

Some wetland valuation studies assume a single value perspective, i.e., estimation of the value of wetlands with respect to a single ecological service. For example, recreational fishing value of wetlands in Michigan were valued at \$18 million per year [15]. Similarly, [16] estimated the recreational value of wetlands in San Joaquin valley at $\$ 141$ million. Although the estimated values are not necessarily incorrect, they could underrepresent the value of wetlands due to the single value perspective, because we know that wetlands have multiple values arising from numerous functions performed simultaneously in varying degrees $[1,4]$. Through this study, we aim to assess the value to society of actions to mitigate wetland loss along with the assumption that these restored wetlands offer several services that are part of the joint economic product.

\section{Methods}

To evaluate the ecosystem service value of wetland mitigation, we relied on the information in the Corps wetland-permit-files issued during 2010-2012 in the continental U.S. Included in the wetland permit files are the location of impact, nature of impact, size of impact, type of wetland, type of mitigation, and size of mitigation. During 2010-2012, 72,000 compensatory wetland acres were required to mitigate for impacts to 30,000 wetland acres approved through 143,197 permits across the continental U.S. (Table 1). It is important to recognize that a variety of activities and natural processes not necessarily requiring a Section 404 permit could influence wetland acreages. The impacted and mitigation acres reported here are for activities that required a Section 404 permit and are recorded in the permit files. Hence, the wetland numbers might not necessarily reflect accurate wetland acreage changes in the U.S. that occurred during the 2010-2012 period.

Table 1. Numbers of permits issued, area of wetland impacted, and required mitigation acres involved in 404 permits in the continental U.S. during 2010-2012 a

\begin{tabular}{cccc}
\hline State & Permits Verified or Issued & Wetland Acres Impacted & Wetland Mitigation Acres Required \\
\hline Alabama & 2303 & 417.3 & 401.2 \\
\hline Arkansas & 5686 & 293.4 & 349.0 \\
\hline Arizona & 946 & 126.2 & 38.5 \\
\hline California & 8998 & 3007.5 & 4571.8 \\
\hline Colorado & 2473 & 155.7 & 135.4 \\
\hline Connecticut & 791 & 37.5 & 238.0 \\
\hline Delaware & 179 & 13.7 & 1.9 \\
\hline Florida & 4927 & 7677.5 & $22,749.1$ \\
\hline Georgia & 2316 & 888.4 & 652.4 \\
\hline Iowa & 2369 & 347.6 & 452.8 \\
\hline Idaho & 1530 & 99.9 & 170.9 \\
\hline Illinois & 4264 & 413.5 & 543.4 \\
\hline
\end{tabular}


Table 1. Cont.

\begin{tabular}{|c|c|c|c|}
\hline State & Permits Verified or Issued & Wetland Acres Impacted & Wetland Mitigation Acres Required \\
\hline Indiana & 2901 & 1480.0 & 1811.3 \\
\hline Kansas & 2517 & 394.2 & 934.1 \\
\hline Kentucky & 2057 & 360.1 & 677.4 \\
\hline Louisiana & 6282 & 2589.2 & 7978.7 \\
\hline Massachusetts & 995 & 160.2 & 158.3 \\
\hline Maryland & 2774 & 964.0 & 75.6 \\
\hline Maine & 1012 & 117.5 & 5136.3 \\
\hline Michigan & 2481 & 137.7 & 74.7 \\
\hline Minnesota & 3374 & 1319.1 & 707.9 \\
\hline Missouri & 5972 & 193.9 & 279.2 \\
\hline Mississippi & 1515 & 1397.6 & 2730.0 \\
\hline Montana & 1896 & 53.7 & 482.2 \\
\hline North Carolina & 3891 & 543.5 & 1190.7 \\
\hline North Dakota & 1843 & 236.9 & 144.6 \\
\hline Nebraska & 1549 & 304.2 & 1061.1 \\
\hline New Hampshire & 1603 & 144.2 & 2983.3 \\
\hline New Jersey & 567 & 72.6 & 119.2 \\
\hline New Mexico & 735 & 45.0 & 44.1 \\
\hline Nevada & 476 & 36.3 & 16.4 \\
\hline New York & 4532 & 431.3 & 1390.3 \\
\hline Ohio & 2092 & 405.3 & 375.5 \\
\hline Oklahoma & 1689 & 108.9 & 208.4 \\
\hline Oregon & 2014 & 446.7 & 292.2 \\
\hline Pennsylvania & 19,032 & 313.3 & 282.7 \\
\hline Rhode Island & 189 & 9.0 & 0.1 \\
\hline South Carolina & 1347 & 258.0 & 4470.7 \\
\hline South Dakota & 1127 & 158.5 & 70.8 \\
\hline Tennessee & 4213 & 325.5 & 882.0 \\
\hline Texas & 4977 & 1564.0 & 3775.3 \\
\hline Utah & 1471 & 105.1 & 166.1 \\
\hline Virginia & 4780 & 626.5 & 1261.5 \\
\hline Vermont & 756 & 48.2 & 323.2 \\
\hline Washington & 2423 & 317.0 & 723.7 \\
\hline Wisconsin & 5457 & 712.2 & 609.7 \\
\hline West Virginia & 2799 & 81.1 & 100.0 \\
\hline Wyoming & 3077 & 191.0 & 247.7 \\
\hline Total & 143,197 & $30,129.5$ & $72,088.5$ \\
\hline
\end{tabular}

${ }^{\text {a }}$ An additional 2399 permits were issued involving 3700 acres of wetlands to mitigate 1800 acres of permitted wetland losses in Alaska, Hawaii, and other U.S. territories during 2010-2012; Wetland data obtained from U.S. Army Corps permit files; Note: It is important to recognize that not every permit requires compensatory mitigation rather only a subset of permits requires compensatory mitigation. 
The data indicate that on-site and off-site permittee responsible compensatory mitigation account for $65 \%$ of the total proportion of required wetland compensation nationwide during 2010-2012. Whereas, purchasing mitigation credits from mitigation banks and payment to an in lieu-fee program account for $26 \%$ and $9 \%$, respectively, of the total required wetland compensation. The nature of the permit data analyzed in this report are insufficient to assess whether permitees fully complied with the terms of the permits or whether the compensatory wetland fully replaced the ecological functions of the wetlands destroyed. However, for the purpose of analysis in this paper, we assume mitigation requirements reported in the permit files represent a successful wetland creation.

The ability to monetize benefits and compare mitigation using a common metric is often sacrificed by the cost and complexity of valuation methods. Partly as a response to this situation, vast amount of literature on wetland valuation could be used for research synthesis, in particular meta-analysis [17]. Meta-analysis is a quantitative analysis of statistical summary indicators reported in a series of similar empirical studies. It extends beyond simple literature review [17]. In this case, it is a comprehensive review of empirical wetland valuation literature on that appeared over the last 25 years. The meta-regression generally includes socio-economic variables and geo-referenced variables in the form of GDP per capita, population, as well as variables reflecting wetland services. Such a rigorous analysis facilitates value transfer to other non-valued sites as an alternative to primary valuation.

The approach of value transfer adopted in this paper is value-function transfer, i.e., transferring values to a site of interest using a value transfer function. It is generally accepted that function transfer performs better than value-estimate transfer because the former is based on information from a large number of studies, could be controlled for methodological differences between primary valuation studies $[18,19]$. But, we acknowledge that any bias associated with each valuation study used in the meta-analysis could be carried over to the study using the meta-regression function, hence, warrant primary valuation studies. Nevertheless, carefully conducted value transfer studies can limit such errors, increase the accuracy of estimates while limiting the time and cost involved in primary valuation studies.

The wetland value per acre estimation is based on the results of meta-analysis of wetland value per acre literature conducted by [20]. Their meta-analysis examines the valuation literature of wetlands located in the U.S. Their analysis included 72 observations of wetland value per acre identified from 33 studies. Along with the annual value per acre variable in their meta-regression equation, included are wetland physical characteristic variables, wetland geographical characteristic variables, socio-economic variables, and study-related variables. Regional variability of wetlands location is controlled by including variables characterizing geographic location of wetlands. The regions included in the model are heartland, northern crescent, northern great plains, fruitful rim, Mississippi portal, southern seaboard, prairie gateway, and eastern uplands. Estimated coefficients of variables included in their wetland metaregression are presented in Table A1. The meta-regression function transfer approach adopted in the current analysis is based on the premise that the marginal impact of each of the significant variables is accounted to provide an estimate of the consumer surplus value per acre for each ecosystem service included in the estimation.

The estimation is carried out using a pre-programmed input sheet, presented in Table 2, developed off the meta-analysis results of [20]. The wetland value per acre input screen allows entering wetland physical and geographical characteristics related information, socio-economic related information, and ecosystem services presumed-supported information [21]. Once this information is obtained and entered, 
individual ecosystem value per acre of wetland per year is estimated based on the results of wetland meta-analysis conducted by [20]. To the extent that several of the ecosystem services offered by wetlands are noncompetitive and exhibit public good nature [2,8], aggregate ecosystem value per acre is estimated by multiplying the ecosystem value per acre of each service generated by wetlands with the number of households within each state [22]. Furthermore, annual value of total mitigation wetland acres is estimated by multiplying aggregate ecosystem value per acre times the total mitigation acres within a particular state. The author acknowledges that not all ecosystem services have public good nature and/or exhibit varying levels of public good nature by individual ecosystem services, which could lead to some overestimation of the aggregate ecosystem value.

Table 2. Preprogrammed input sheet for valuing total economic value of wetlands ${ }^{\mathbf{a}}$.

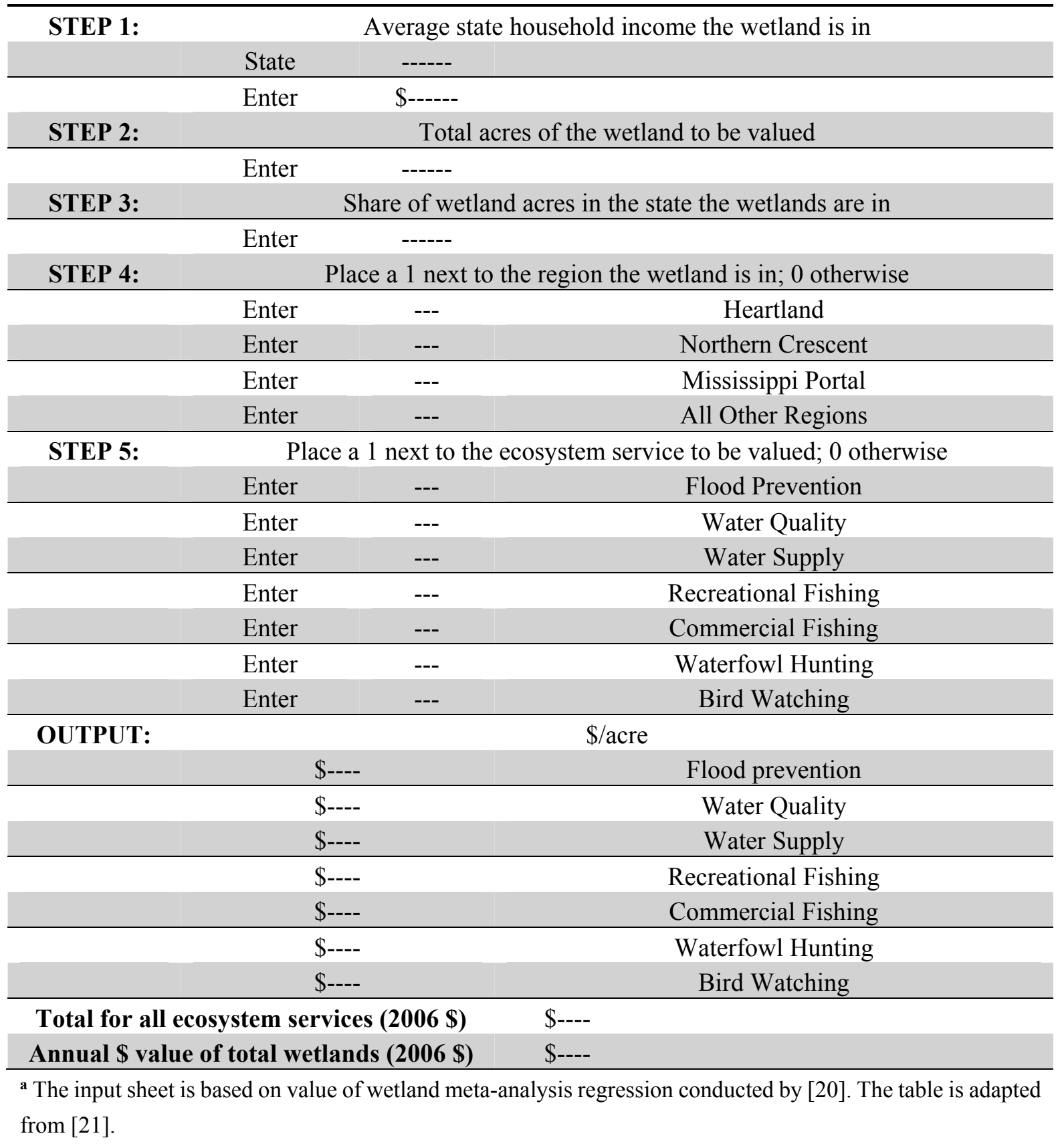




\section{Results and Discussion}

The results indicate that recreation, water quality services, water supply, and commercial fishing are relatively highly valued services. Table 3 is a presentation of the national estimates of the annual average benefit value per acre for individual ecosystem services, aggregate annual average benefit value per acre, aggregate benefit value per year for all mitigation acres. Annual average value per acre is in the range of $\$ 5000$ to $\$ 70,000$ with an overall average of $\$ 37,900$ in 2010 dollars. In a similar nationwide valuation analysis by the U.S. EPA and the USACOE [23], annual average value per acre was estimated to be in the range of $\$ 129,000$ to $\$ 292,000$, also in 2010 dollars. The EPA identified 10 studies that provided estimates of WTP from wetland valuation literature, i.e., 10 studies were used in their meta-analysis function to derive an average WTP value. Their basis for selecting the 10 studies is unclear in the report. Whereas, the current analysis is based off meta-analysis function derived from 33 studies consisting of 72 WTP estimates. Therefore, the average per acre values estimated in this analysis reflect estimates derived from large pool of relevant literature thus providing a more comprehensive meta-analysis of the valuation literature.

Applying the per acre estimate to the number of mitigation wetland acres results in a cumulative benefit of \$2.7 billion per year. Aggregate annual average benefits of recreation, i.e., value for fishing, waterfowl hunting, and bird watching amount to $\$ 164.5, \$ 169.9$, and $\$ 804.9$ million, respectively in 2010 dollars (Table 3). It is well known that wetland habitats offer many recreational services and those services are well recognized by citizens. The estimated recreational values reiterate the fact that wetlands support a large recreational sector and warrants efforts for wetlands protection through establishment, preservation, and/or enhancement.

Value of water quality improvement/protection and water supply amount to $\$ 575.7$ and $\$ 424.0$ million per year, respectively, also in 2010 dollars (Table 3). Similar results were found, where water quality improvement was among the three highest valued ecosystem services of wetlands [24]. Studies have shown that wetlands properly constructed and maintained could be effective for protecting water quality $[25,26]$. With several water quality stressors such as agriculture [27], urban development, population growth, and atmospheric deposition [28], the value of wetlands for water quality improvement is not unrealistic. Moreover, wetlands are central components of aquatic ecosystems, an interdependence that provides strong scientific justification for policies that make a connection between clean water and the protection of wetland ecosystems [29].

Fish and shellfish species dependent on wetlands for food or habitat comprise more than $75 \%$ of the commercial harvest [30]. Hence, the value of wetlands as a commercial fishing resource is indicative of the economic benefits to fishermen and their communities. The value of commercial fishing was among the top three values of ecosystem services, with aggregate acreage benefits of $\$ 489.6$ million per year in 2010 dollars (Table 3). Other studies that estimated value of wetlands as key environments include [31], where wetlands were found to be both ecologically and economically important habitats.

Although factors such as intensity of the storm and the number of storm events play a key role in storm damages, wetlands are key to minimizing the storm impacts. They provide a buffer zone between storm landfall and coastal communities [5,32]. Aggregate benefits associated with wetland mitigation for flood protection services are estimated at \$103.9 million per year in 2010 dollars (Table 3). These substantial ecosystem value estimates provide strong justification to wetland protection and restoration. 
Table 3. National annual average benefit value per acre for individual ecosystem service and aggregate value for ecosystem service per year produced by wetlands mitigation required under Section 404 of the Act ${ }^{\text {a }}$.

\begin{tabular}{|c|c|c|c|c|}
\hline Ecosystem Service & $\begin{array}{c}\text { Annual Average } \\
\text { Benefit Value } \\
\text { per Acre }(\$)\end{array}$ & $\begin{array}{c}\text { Annual Average } \\
\text { Benefit Value per Acre } \\
\text { (Lower Bound) }{ }^{\mathbf{b}}(\$)\end{array}$ & $\begin{array}{c}\text { Annual Average } \\
\text { Benefit Value per Acre } \\
\text { (Upper Bound) }{ }^{\mathbf{b}}(\$)\end{array}$ & $\begin{array}{c}\text { Annual Aggregate } \\
\text { Benefit Value } \\
\left(\text { All Acres) }{ }^{c}(\$)\right.\end{array}$ \\
\hline Recreational Fishing & 2288 & 318 & 4264 & $164,966,956$ \\
\hline Bird Hunting & 2358 & 328 & 4394 & $169,992,059$ \\
\hline Bird Watching & 11,166 & 1552 & 20,806 & $804,921,255$ \\
\hline $\begin{array}{c}\text { Water Quality } \\
\text { Protection }\end{array}$ & 7987 & 1111 & 14,884 & $575,791,305$ \\
\hline $\begin{array}{c}\text { Water Supply } \\
\text { Protection }\end{array}$ & 5882 & 818 & 10,960 & $424,005,540$ \\
\hline Commercial Fishing & 6793 & 944 & 12,658 & $489,676,828$ \\
\hline Flood Control & 1442 & 226 & 2661 & $103,932,362$ \\
\hline $\begin{array}{c}\text { Aggregate annual } \\
\text { average benefit value } \\
\text { per acre }^{\mathbf{d}} \\
\end{array}$ & 37,915 & 5297 & 70,628 & \\
\hline $\begin{array}{l}\text { Annual value of } \\
\text { total wetlands }\end{array}$ & & & & $2,733,286,304$ \\
\hline
\end{tabular}

a All dollar values are adjusted to 2010 \$ using Consumer Price Index. Values rounded to the nearest whole number; ${ }^{\mathbf{b}}$ Represent $90 \%$ confidence intervals; ${ }^{\mathbf{c}}$ The aggregate benefits for each ecosystem service is derived by multiplying the average value per acre times the total mitigation acres; ${ }^{\mathbf{d}}$ The value reflects the aggregation of ecosystem services value of mitigation acres across all states within continental U.S.; ${ }^{\text {e }}$ Derived by multiplying aggregate average value per acre per year times the total mitigation acres. The lower and upper bounds for value of total wetlands are $\$ 381,382,447$ and $\$ 5,085,190,162$, respectively.

Statewide total value associated with wetland mitigation are presented in Table 4. It is interesting to note that these ecosystem services values were relatively higher in the Northeast and most of the Great Lakes states. For example, annual total value per acre for all ecosystem services range from as low as $\$ 1000$ in Louisiana to as high as $\$ 500,000$ in Connecticut. One possible explanation for this disparity is that wetlands occupy $33 \%$ of the area in the state of Louisiana, whereas they occupy only $10 \%$ of the area in the state of Connecticut. Hence, it is reasonable to assume that an acre of wetland would be valued relatively higher in a region where the resource is relatively scarce and/or exclusive. But, this does not necessarily mean that the value of an additional acre of wetlands in states with greater share of wetlands is low, but the notion of a similar resource available elsewhere in the state/region could influence the value of wetlands. 
Table 4. Statewide annual aggregate benefit values, their lower and upper bound estimates, and annual value of total wetland mitigation acres in the continental U.S. under Section 404 of the Act ${ }^{\text {a }}$.

\begin{tabular}{|c|c|c|c|c|}
\hline State & $\begin{array}{c}\text { Annual Aggregate } \\
\text { Benefit Value per Acre }^{\text {b }}(\$)\end{array}$ & $\begin{array}{c}\text { Annual Aggregate } \\
\text { Benefit Value per Acre } \\
\text { (Lower Bound) (\$) }\end{array}$ & $\begin{array}{c}\text { Annual Aggregate } \\
\text { Benefit Value per Acre } \\
\text { (Upper Bound) (\$) }\end{array}$ & $\begin{array}{c}\text { Annual Aggregate } \\
\text { Benefit Value } \\
\text { (All Acres) (\$) } \\
\end{array}$ \\
\hline Alabama & 2091 & 909 & 3273 & 838,956 \\
\hline Arkansas & 2903 & 1262 & 4544 & $1,012,968$ \\
\hline Arizona & 8458 & 3677 & 13,238 & 325,447 \\
\hline California & 19,246 & 8368 & 30,125 & $87,989,362$ \\
\hline Colorado & 12,737 & 5538 & 19,936 & $1,724,291$ \\
\hline Connecticut & 535,017 & 232,608 & 837,427 & $127,344,841$ \\
\hline Delaware & 5638 & 2451 & 8825 & 10,712 \\
\hline Florida & 2096 & 911 & 3280 & $47,677,575$ \\
\hline Georgia & 3182 & 1384 & 4981 & $2,075,930$ \\
\hline Iowa & 38,029 & 16,535 & 59,523 & $17,217,829$ \\
\hline Idaho & 5221 & 2270 & 8172 & 892,154 \\
\hline Illinois & 74,690 & 32,473 & 116,907 & $40,587,893$ \\
\hline Indiana & 40,321 & 17,531 & 63,111 & $73,033,977$ \\
\hline Kansas & 6575 & 2859 & 10,292 & $6,141,751$ \\
\hline Kentucky & 3658 & 1591 & 5726 & $2,478,185$ \\
\hline Louisiana & 1029 & 447 & 1611 & $8,210,518$ \\
\hline Massachusetts & 416,547 & 181,101 & 651,994 & $65,935,261$ \\
\hline Maryland & 23,984 & 10,427 & 37,540 & $1,813,407$ \\
\hline Maine & 36,030 & 15,665 & 56,396 & $185,061,105$ \\
\hline Michigan & 97,827 & 42,532 & 153,122 & $7,306,696$ \\
\hline Minnesota & 142,106 & 61,783 & 222,428 & $100,600,813$ \\
\hline Missouri & 33,445 & 14,539 & 52,351 & $9,336,954$ \\
\hline Mississippi & 1720 & 748 & 2693 & $4,696,363$ \\
\hline Montana & 4224 & 1837 & 6612 & $2,036,968$ \\
\hline North Carolina & 2545 & 1106 & 3984 & $3,030,237$ \\
\hline North Dakota & 3353 & 1458 & 5248 & 484,885 \\
\hline Nebraska & 6289 & 2734 & 9844 & $6,672,888$ \\
\hline New Hampshire & 460,376 & 200,156 & 720,596 & $1,373,426,099$ \\
\hline New Jersey & 528,362 & 229,714 & 827,010 & $62,954,355$ \\
\hline New Mexico & 4504 & 1958 & 7050 & 198,501 \\
\hline Nevada & 14,202 & 6175 & 22,230 & 233,445 \\
\hline New York & 178,529 & 77,619 & 279,440 & $248,212,142$ \\
\hline Ohio & 36,431 & 15,839 & 57,024 & $13,678,916$ \\
\hline Oklahoma & 3615 & 1572 & 5658 & 753,412 \\
\hline Oregon & 6797 & 2955 & 10,638 & $1,985,732$ \\
\hline Pennsylvania & 170,217 & 74,005 & 266,430 & $48,119,584$ \\
\hline Rhode Island & 180,904 & 78,651 & 283,158 & 21,709 \\
\hline South Carolina & 1712 & 744 & 2679 & $7,652,204$ \\
\hline South Dakota & 4382 & 1905 & 6859 & 310,176 \\
\hline Tennessee & 5910 & 2570 & 9251 & $5,212,929$ \\
\hline
\end{tabular}


Table 4. Cont.

\begin{tabular}{|c|c|c|c|c|}
\hline State & $\begin{array}{c}\text { Annual Aggregate Benefit Value } \\
\operatorname{per}^{\operatorname{Acre}^{\text {b }}(\$)}\end{array}$ & $\begin{array}{c}\text { Annual Aggregate } \\
\text { Benefit Value per Acre } \\
\text { (Lower Bound) (\$) }\end{array}$ & $\begin{array}{c}\text { Annual Aggregate } \\
\text { Benefit Value per Acre } \\
\text { (Upper Bound) (\$) }\end{array}$ & $\begin{array}{c}\text { Annual Aggregate } \\
\text { Benefit Value } \\
\text { (All Acres) (\$) } \\
\end{array}$ \\
\hline Texas & 5763 & 2505 & 9020 & $21,755,423$ \\
\hline Utah & 10,676 & 4642 & 16,711 & $1,773,438$ \\
\hline Virginia & 14,626 & 6359 & 22,893 & $18,449,834$ \\
\hline Vermont & 139,714 & 60,743 & 218,685 & $45,152,855$ \\
\hline Washington & 12,490 & 5430 & 19,550 & $9,039,297$ \\
\hline Wisconsin & 110,833 & 48,186 & 173,479 & $67,571,398$ \\
\hline West Virginia & 2571 & 1118 & 4025 & 257,002 \\
\hline Wyoming & 8033 & 3493 & 12,574 & $1,989,890$ \\
\hline \multicolumn{2}{|c|}{ Annual value of total wetlands ${ }^{c}$} & & & $2,733,286,304$ \\
\hline
\end{tabular}

a All dollar values are in 2010 \$, adjusted using Consumer Price Index. Values rounded to the nearest whole number. Reported are 95\% confidence intervals; ${ }^{\mathbf{b}}$ Annual aggregate value per acre include value of all the ecosystem services identified in Table $3 ;{ }^{\mathbf{c}}$ The lower and upper bounds of annual value of total wetlands are $\$ 381,382,447$ and $\$ 5,085,190,162$, respectively.

\section{Conclusions}

As public goods, wetlands and their services are often undervalued and underprovided. Although wetlands provide valuable ecological services, there remains substantial debate about the extent to which resources should be allocated for their protection, restoration, and whether certain wetlands deserve protection at all. Section 404 of the CWA includes most wetlands in the U.S. in its jurisdiction and requires wetland mitigation to compensate for permitted wetland losses. Failure to quantify the ecosystem services value provided on mitigation wetland acres could result in these wetlands being given too little weight in policy decisions.

A benefit value-function transfer approach is adopted to derive the ecosystem values. The value-function is derived from meta-analysis of wetland valuation literature, conducted by [20]. To derive the ecosystem value estimates, wetland mitigation requirements for permitted wetland losses during 2010-2012 across continental U.S. are used. Given the nature of the data, it was assumed that mitigation requirements recorded in the permit files reflect actual wetland creation. Results indicate that annual aggregate benefit value per acre for all ecosystem services is in the range of $\$ 5000$ to $\$ 70,000$. Annual value of total mitigation wetlands was estimated as $\$ 2.7$ billion per year. Although there were considerable limitations to this approach, the metrics do provide some guidance about the value of the services generated as a result of the current wetland mitigation policy. Nevertheless, continual improving our methods for estimating goods and services will be essential for ameliorating wetlands habitat protection.

Impacts to different wetland types are not the same, and the required mitigation does not always result in the in-kind replacement of lost wetlands [33] that sometimes results in over-estimation of the functional values. In addition, there could be some double counting when adding estimates of ecosystem services, as not all wetlands fully perform all of the functions evaluated. However, given some of the uncertainties involved, we may never have a very precise estimate of the value of ecosystem services. Nevertheless, the ecosystem service value estimated in this paper provide a strong rationale for wetland protection through establishment, preservation, and/or enhancement. Given that ecosystem services have 
historically been inadequately identified and quantified, the values derived provide an initial step in understanding the value of wetland mitigation. Although permitted wetland losses might justify for economic development, the substantial ecosystem values identified in this analysis necessitates enforcement of full compliance to the mitigation requirements. Moreover, most decisions on natural resource use are made on economic grounds [34]. Ecological values that are often expressed through indicators such as species variety, diversity, and integrity [35], socio-cultural values that reflect ethical, religious, and spiritual values [36] are seldom considered due to the difficulty to record and articulate these values. Such under valuation of the benefits of natural systems often leads to destruction of the natural ecosystems at the expense of our own welfare and future generations [37]. But, our knowledge of these values is still insufficient to support effective policy-making and management. Nevertheless, there has been a substantial progress in valuing wide range of goods and services through growing number of studies in ecosystem valuation. The values generated through this exercise can allow for comparison of the economic benefits of such wetland-offset sites to natural landscapes, the benefits that accrue to local societies and at global scale albeit most benefits are not captured through market based economic analysis.

Policies have been put in place to conserve wetland habitats, which are a result of recent recognition of the magnitude of wetland capabilities to provide multiple ecosystem services. Similarly, policies have been evolving to protect wetlands better, but more focus is warranted on ways to improve protection and ensure success of mitigation. Several authors that studies mitigation recommend improved documentation, increased permit follow up, and monitoring [29,33] for the success of wetland mitigation.

The current shortcoming of the wetland permit system is having no expectations to replace wetland functions. Emphasis should be placed not only on acreage but also on mitigation compliance as well as on ecosystem functions restoration. Accounting for the value of the ecosystem functions will challenge the argument of high costs to replace wetland functions. It is very likely that the value of the benefits will substantially outweigh the replacement costs. Finally, it is clear that replacing the vegetative cover alone will not ensure successful wetland mitigation, rather replacing wetland functions coupled with monitoring will help stem the losses of these valuable habitats.

Economic tradeoffs exist in wetland conversion. Profit from natural wetland conversions result in costs from loss in ecosystem services such as habitat loss, flood damage, to name a few. The current metrics used to determine the success of compensatory mitigation are inadequate to assess and manage the natural systems that are often converted to human infrastructure development. The majority of the assessments are acreage based and provide little indication of the economic benefit of ecosystem protection [11]. Many are concerned that an acre for acre or even an acre for two emphasis for measurability will cause functions, which are hard to observe and quantify to be lost. To determine the implications of current mitigation policy, quantification of the benefit value of the ecosystem services will add the economic assessment to the physical and ecological assessment of the wetlands mitigation policy. The quantification of ecosystem services of wetlands will aid in land use planning by allowing cost-benefit comparison to protect and/or restore ecosystems. It allows decision makers to justify public spending on wetland management activities [38]. The quantification provides the information to assess the tradeoffs between economic benefits and environmental risks of converting one land use type to another land use type.

Wetlands impacts for which mitigation is required under Section 10 and Section 404, emphasis on acreage alone is insufficient for the implementation of mitigation policy. Improvement of monitoring 
requirements coupled with rigorous economic assessment is critical for success of mitigation program. To enable conservation-oriented management, it is important to have ecosystem service values that can provide a comprehensive investigation of the mitigation policy. Also, missing from the debate is the evidence on conversion of wetlands affecting the GHG balance in the atmosphere. While acknowledging that the carbon sequestration potential of wetlands could be difficult to estimate, we believe that incorporating better climate change assessment tools into the decision process provides policy makers and businesses with better information to guide their current conservation efforts that would enhance wetland protection.

\section{Acknowledgments}

The primary author worked on this project when housed at Natural Resources Defense Council. The author would like to thank Natural Resources Defense Councils' Science Center for its financial support to conduct this research. The author would like to extend sincere thanks to Jon Devine, John Loomis, Bowman Cutter, Robert Adler, and James Boyce for their valuable comments and input throughout the process of the research. Any opinions, findings, and conclusions or recommendations expressed in this research are those of the author and do not necessarily reflect the views of the Natural Resources Defense Council or the author current employers.

\section{Appendix}

Table A1. Description of variables and regression coefficients from meta-analysis of wetland value per acre estimates conducted by [20].

\begin{tabular}{ccc}
\hline Variable & Coefficient & Standard Errors \\
\hline Socio-economic & & \\
\hline Income & 0.095 & 0.059 \\
\hline Year & $0.197 * * *$ & 0.053 \\
Wetland size & & \\
\hline Acres & $-3.85 \times 10^{-7}$ & 0.000 \\
\hline Share & -5.415 & 3.905 \\
\hline Wetland type & & \\
\hline Freshwater Marsh & -1.088 & 1.186 \\
\hline Saltwater Marsh & $-2.087 *$ & 1.136 \\
\hline Prairie Pothole & -1.961 & 1.516 \\
\hline Wetland functions & & \\
\hline Water Supply & 0.929 & 1.016 \\
\hline Water Quality & 1.235 & 0.738 \\
\hline Flood Protection & -0.477 & 0.626 \\
\hline Recreational Fishing & -0.015 & 0.613 \\
\hline Commercial Fishing & 1.073 & 0.899 \\
\hline Bird Hunting & $0.015 *$ & 0.651 \\
\hline Bird Watching & 1.57 & 0.825 \\
\hline Amenity Value & -1.518 & 0.972 \\
\hline Habitat Value & 0.023 & 0.711 \\
\hline
\end{tabular}


Table A1. Cont.

\begin{tabular}{ccc}
\hline Variable & Coefficient & Standard Errors \\
\hline Valuation method & & \\
\hline Contingent valuation & -1.437 & 0.989 \\
\hline Hedonic pricing & -0.154 & 1.617 \\
\hline Travel cost & -0.658 & 1.150 \\
\hline Net factor income & 0.628 & 1.237 \\
\hline Production function & $-1.827 *$ & 1.057 \\
\hline Location of wetlands & & \\
\hline Heartland & 1.316 & 1.059 \\
\hline Northern Crescent & $2.681^{* *}$ & 1.008 \\
\hline Mississippi Portal & -0.158 & 1.919 \\
\hline All Other Regions & -0.585 & 0.832 \\
\hline Type of study & & 1.025 \\
\hline Published study & $2.489 * *$ & 2.861 \\
\hline Intercept & -2.297 & \\
\hline
\end{tabular}

Note: Adapted from [20]; Seventy-two observations of US wetland value per acre from thirty-three studies are used toward meta-analysis. Readers are encouraged to refer to [20] for the studies used to identify the wetland value observations.

\section{Conflicts of Interest}

The author declare no conflict of interest.

\section{References}

1. Larson, J.S.; Adamus, P.R.; Clairain, E.J. Functional Assessment of Freshwater Wetlands: A Manual and Training Outline; University of Massachusetts: Amherst, MA, USA, 1989.

2. National Research Council. Valuing Ecosystem Services: Toward Better Environmental Decision-Making; The National Academies Press: Washington, DC, USA, 2005.

3. Lynne, G.D.; Conroy, P.D.; Prochaska, F.J. Economic valuation of marsh areas for marine production processes. J. Environ. Econ. Manag. 1981, 8, 175-186.

4. Raphael, C.N.; Jaworski, E. Economic value of fish, wildlife, and recreation in Michigan's coastal wetlands. J. Coast. Zone Manag. 1979, 5, 181-194.

5. Costanza, R.; Perez-Maqueo, O.; Martinez, M.L.; Sutton, P.; Anderson, S.J.; Mulder, K. The value of coastal wetlands for hurricane protection. Ambio 2008, 37, 241-248.

6. Dahl, T.E. Wetland Losses in the United States, 1780's to 1980's; U.S. Department of the Interior, Fish and Wildlife Service: Washington, DC, USA, 1990.

7. Dahl, T.E. Status and Trends of Wetlands in the Conterminous United States, 2004 to 2009; Department of the Interior, Fish and Wildlife Service: Washington, DC, USA, 2011.

8. The Conservation Foundation. Protecting America's Wetlands: An Action Agenda. The Final Report of the National Wetlands Policy Forum; Report No. 00479143; Conservation Foundataion: Washington, DC, USA, 1988. 
9. USDA-Natural Resources Conservation Service. Assessment Methods. Available online: http://www.nrcs.usda.gov/ (accessed on 2 February 2015).

10. Sifneos, J.C.; Cake, E.W., Jr.; Kentula, M.E. Effects of Section 404 permitting on freshwater wetlands in Louisiana, Alabama, and Mississippi. Wetlands 1992, 12, 28-36.

11. Cole, C.A.; Shafer, D. Section 404 wetland mitigation and permit success criteria in Pennsylvania, USA, 1986-1999. Environ. Manag. 2002, 30, 508-515.

12. Salzman, J.; Thompson, B.H.J.; Daily, G.C. Protecting ecosystem services: Science, economics, and law. Stanford Environ. Law J. 2001, 20, 309-332.

13. Daily, G. Nature's Services: Societal Dependence on Natural Ecosystems; Island Press: Covelo, CA, USA, 1997.

14. Shabman, L.; Stephenson, K.; Scodari, P. Wetland credit sales as a strategy for achieving no-net loss: The limitations of regulatory conditions. Wetlands 1998, 18, 471-481.

15. Amacher, G.S.; Brazee, R.J.; Bulkley, J.W.; Moll, R.A. Application of Wetland Valuation Techniques: Examples from Great Lakes Coastal Wetlands; University of Michigan, School of Natural Resources: Ann Arbor, MI, USA, 1989.

16. Creel, M.; Loomis, J. Recreation value of water to wetlands in the San-Joaquin valley_Linked multinomial logit and count data trip frequency models. Water Resour. Res. 1992, 28, 2597-2606.

17. Stanley, T.D. Wheat from chaff: Meta-analysis as quantitative literature review. J. Econ. Perspect. 2001, 15, 131-150.

18. Brander, L.M.; Florax, R.J.G.M.; Vernaat, J.E. The empirics of wetland valuation: A comprehensive summary and a meta-analysis of the literature. Environ. Resour. Econ. 2006, 33, 223-250.

19. Bateman, I.; Jones, L.P. Contrasting conventional with multi-level modeling approaches to meta-analysis: Expectation consistency in U.K. Woodland recreation values. Land Econ. 2003, 79, 235-258.

20. Borisova-Kidder, A. Meta-Analytical Estimates of Values of Environmental Services Enhanced by Government Agricultural Conservation Programs. Ph.D. Thesis, Ohio State University, Columbus, OH, USA, 2006.

21. Loomis, J.; Richardson, L. Technical Documentation of Benefit Transfer and Visitor Use Estimating Models of Wildlife Recreation, Species, and Habitats; Colorado State University, Department of Agricultural and Resource Economics: Fort Collins, CO, USA, 2008.

22. Johnson, C.W.; Linder, R.L. An economic valuation of South Dakota wetlands as a recreation resource for resident hunter. Landsc. J. 1986, 5, 33-38.

23. U.S. Environmental Protection Agency (EPA); United States Army Corps of Engineers (USACOE). Economic Analysis of Proposed Revised Definition of Waters of the United States; U.S. EPA: Washington, DC, USA, 2013.

24. Ghermandi, A.; Vanden-Bergh, J.C.J.M.; Brander, L.M.; de Groot, H.L.F.; Nunes, P.A.L.D. Values of natural and human-made wetlands: A meta-analysis. Water Resour. Res. 2010, doi:10.1029/2010WR009071.

25. Reed, S.C. Constructed wetlands for wastewater treatment. Biocycle 1991, 32, 44-49.

26. Kadlec, R.H.; Knight, R.L. Treatment Wetlands; Lewis Publishing: New York, NY, USA, 1996. 
27. Morrice, J.A.; Nicholas, P.; Danz, P.; Regal, R.R.; Kelly, J.R.; Niemi, G.J.; Reavie, E.D.; Hollenhorst, T.; Axler, R.P.; Trebitz, A.S.; et al. Human influences on water quality in Great Lakes coastal wetlands. Environ. Manag. 2008, 41, 347-357.

28. Danz, N.P.; Niemi, G.J.; Regal, R.R.; Hollenhorst, T.; Johnson, L.B.; Hanowski, J.M.; Axler, R.P.; Ciborowski, J.J.H.; Thomas, H.; Brady, V.J.; et al. Integrated gradients of anthropogenic stress in the U.S. Great Lakes basin. Environ. Manag. 2007, 39, 631-647.

29. National Research Council. Wetlands: Characteristics and Boundaries; The National Academies Press: Washington, DC, USA, 1995.

30. U.S. Environmental Protection Agency (EPA). Economic Benefits of Wetlands; EPA Report No. EPA843-F-06-004; Office of Water: Washington, DC, USA, 2006.

31. Farber, S.; Costanza, R. The economic value of wetlands systems. J. Environ. Econ. Manag. 1987, 24, 41-51.

32. Farber, S. The value of coastal wetlands for protection of property against hurricane wind damage. J. Environ. Econ. Manag. 1987, 14, 143-151.

33. Holland, C.C.; Kentula, M.E. Impacts of Section 404 permits requiring compensatory mitigation on wetlands in California, USA. Wetlands Ecol. Manag. 1992, 2, 157-169.

34. Emerton, L.; Bos, E. Value-Counting Ecosystems as An Economic Part of Water Infrastructure; International Union for Conservation of Nature; International Union for Conservation of Nature (IUCN): Gland, Switzerland; Cambridge, UK, 2004; p. 88.

35. De Groot, R.S.; van der Perk, J.P.; Chiesura, A.; van Vliet, A.J.H. Importance and threat as determining factors for criticality of natural capital. Ecol. Econ. 2003, 44, 187-204.

36. Millennium Ecosystem Assessment (MEA). Ecosystems and Human Well-Being: A Frameworkfor Assessment; Island Press: Washington, DC, USA, 2003.

37. Costanza, R.; d'Arge, R.; de Groot, R.S.; Farber, S.; Grasso, M.; Hannon, B.; Limburg, K.; Naeem, S.; O'Neill, R.V.; Paruelo, J.; et al. The value of the world's ecosystem services and natural capital. Nature 1997, 387, 253-260.

38. Barbier, E.B.; Acreman, M.; Knowler, D. Economic Valuation of Wetlands; Ramsar Convention Bureau Publication: Gland, Switzerland, 1997; p. 138.

(C) 2015 by the authors; licensee MDPI, Basel, Switzerland. This article is an open access article distributed under the terms and conditions of the Creative Commons Attribution license (http://creativecommons.org/licenses/by/4.0/). 